\title{
Structural and functional consequences of buserelin-induced enteric neuropathy in rat
}

\author{
Elin Sand ${ }^{1,2}$, Bodil Roth', Bjrn Westrm $\quad{ }^{3}$, Peter Bonn $^{4}$, Eva Ekblad ${ }^{2}$ and Bodil Ohlsson ${ }^{1 *}$
}

\begin{abstract}
Background: Women treated with gonadotropin-releasing hormone $(\mathrm{GnRH})$ analogs may develop enteric neuropathy and dysmotility. Administration of a GnRH analog to rats leads to similar degenerative neuropathy and ganglioneuritis. The aim of this study on rat was to evaluate the early GnRH-induced enteric neuropathy in terms of distribution of neuronal subpopulations and gastrointestinal (Gl) function.

Methods: Forty rats were given the $\mathrm{GnRH}$ analog buserelin $(20 \mu \mathrm{g}, 1 \mathrm{mg} / \mathrm{ml})$ or saline subcutaneously, once daily for 5 days, followed by 3 weeks of recovery, representing one treatment session. Two weeks after the fourth treatment session, the animals were tested for GI transit time and galactose absorption, and fecal weight and fat content was analyzed. After sacrifice, enteric neuronal subpopulations were analyzed. Blood samples were analyzed for zonulin and antibodies against $\mathrm{GnRH}$ and luteinizing hormone, and their receptors.
\end{abstract}

Results: Buserelin treatment transiently increased the body weight after 5 and 9 weeks $(p<0.001)$. Increased estradiol in plasma and thickened uterine muscle layers indicate high estrogen activity. The numbers of both submucous and myenteric neurons were reduced by $27 \% 61 \%$ in ileum and colon. The relative numbers of neurons containing calcitonin gene-related peptide (CGRP), cocaine- and amphetamine-related transcript (CART), galanin, gastrin-releasing peptide (GRP), neuropeptide Y (NPY), nitric oxide synthase (NOS), serotonin, substance P (SP), vasoactive intestinal peptide (VIP) or vesicular acetylcholine transporter (VAchT), and their nerve fiber density, were unchanged after buserelin treatment, but the relative number of submucous neurons containing somatostatin tended to be increased $(p=0.062)$. The feces weight decreased in buserelin-treated rats $(p<0.01)$, whereas feces fat content increased $(p<0.05)$, compared to control rats. Total GI transit time, galactose absorption, zonulin levels in plasma, and antibody titers in serum were unaffected by buserelin treatment.

Conclusions: A marked enteric neuronal loss with modest effects on GI function is found after buserelin treatment. Increased feces fat content is suggested an early sign of dysfunction.

Keywords: Enteric neuropathy, Enteric subpopulations, Gastrointestinal (GI) tract, Gonadotropin-releasing hormone $(\mathrm{GnRH})$, Luteinizing hormone $(\mathrm{LH})$, Somatostatin

\section{Background}

A subgroup of patients treated with gonadotropin-releasing hormone $(\mathrm{GnRH})$ analogs develops enteric neuropathy with reduced relative number of GnRH-containing neurons and dysmotility [1,2], and increased abdominal pain and exacerbation of irritable bowel syndrome (IBS) has been observed in a cohort of GnRH-treated women at follow-up, although no obvious dysmotility was at hand

\footnotetext{
* Correspondence: bodil.ohlsson@med.lu.se

'Department of Clinical Sciences, Division of Internal Medicine Skne University Hospital, Lund University, Inga Marie Nilssons street 32, S-205 02 Malm, Sweden

Full list of author information is available at the end of the article
}

[3]. This knowledge rendered us to set up an experimental rat model to examine the effects on the gastrointestinal (GI) tract of systemic and repeated treatment with the $\mathrm{GnRH}$ analog buserelin. About 50\% of enteric neurons were lost throughout the GI tract after four treatment periods of buserelin [4,5]. In addition, myenteric ganglia displayed ganglioneuritis [5] and a significant reduction of the relative number of luteinizing hormone $(\mathrm{LH})$ receptorimmunoreactive neurons [4]. In colon, a transient increase in the relative number of vasoactive intestinal peptide (VIP)-immunoreactive myenteric neurons was found after two treatment periods, and increased relative numbers of 
nitric oxide synthase (NOS)-immunoreactive submucous and myenteric neurons after four treatment periods [4].

The enteric nervous system (ENS) contains a plethora of neurotransmitters, which all participate in the pivotal role of ENS in controlling and modulating GI motility, secretion, and blood flow. The neurotransmitters NOS, pituitary adenylate cyclase-activating peptide (PACAP), purines, somatostatin, and VIP mediate inhibitory transmission, while excitatory transmitters represent acetylcholine, calcitonin gene-related peptide (CGRP), cocaine- and amphetaminerelated transcript (CART), galanin, gastrin-releasing peptide (GRP), neurokinin A, neuropeptide Y (NPY), serotonin (5-hydroxytryptamine; 5 -HT), and substance $\mathrm{P}$ (SP) [6].

There is evidence of a high plasticity of the ENS in response to injurious events in various experimental models, e.g. axotomy, transplantation, hypertrophy, ischemia/ reperfusion, and lipopolysaccharide (LPS) challenge [7-11], as well as in diseases $[12,13]$. Experimental rat models of enteric neuropathy have been described, e.g. neuropathy after cisplatin-, diabetes-, or fat induction [14-16]. Most studies describe pathophysiology and morphological changes in neuropathy, whereas few studies describe any functional consequences on GI motility, nutritional absorption, and intestinal permeability.

The aim of the present study was to describe possible early effects of buserelin-induced enteric neuronal loss on subpopulations of neurons and on body weight, circulating levels of sex hormones and antibodies, GI transit time, feces weight and fat content, nutrient absorption, and epithelial permeability.

\section{Methods}

\section{Animals}

Female Sprague Dawley rats $(\mathrm{n}=40,170180 \mathrm{~g})$, purchased from Charles River, Sulzfeld, Germany, were used. The rats were allowed to acclimatize to the climate- and light-controlled animal facility for at least 5 days prior to experimentation. Standard rat chow ( $4 \%$ fat/g) (Lactamin R36, Stockholm, Sweden) and water were supplied at all times. The experimental design was approved by the Animal Ethics Committee, Lund and Malm, Sweden (M350-12, date of approval: 14.11.12). Animals were used in accordance with the European Communities Council Directive (2010/63/EU) and the Swedish Animal Welfare Act (SFS 1988:534).

\section{Study design}

Twenty-four rats $(\mathrm{n}=24)$ were given $20 \mu \mathrm{g}(1 \mathrm{mg} / \mathrm{ml})$ of the GnRH analog buserelin (Suprefact, Sanofi-Aventis, Bromma, Sweden) subcutaneously, once daily for 5 days, followed by 3 weeks of recovery, representing one session of treatment (for details see ref no. [4]). The dosage and administration of buserelin are based on previous studies which have shown reliable physiological effects in terms of uterine hypertrophy, without any adverse effects $[4,17]$. Control animals $(n=16)$ received saline injections. The animals were weighed prior to inclusion in the study, and weekly in the morning during the study, using an electronic scale. Half of the animals were used to examine vaginal smears. From the other rats (12 buserelintreated and eight saline-treated controls), blood samples were drawn in the morning before administration of buserelin or saline in week 1 and 4 of the injection treatment, and at sacrifice. During the 2 weeks after the fourth treatment session, GI transit time and galactose absorption were studied. Feces were collected during $12 \mathrm{~h}$ of fasting and analyzed for weight and fat content. After sacrifice, tissue samples from the stomach, ileum, transverse colon, and the distal part of the uterine horn were collected and rinsed in saline before fixation and processing for cryo- or paraffin-sectioning and histological evaluation. All methods are described in detail below.

\section{Blood and vaginal sampling}

To study possible buserelin effects on the rat estrus cycle, vaginal smears and blood samples for hormone measurements were collected. On day 0 and 5 during session 1 and 4 , vaginal smears were obtained using a cotton tipped applicator, rotated three times, $2 \mathrm{~cm}$ from the vaginal orifice. The vaginal smears were placed on microscope slides and stained with methylene blue and eosin for determination of the phase in the estrus cycle. The classification of the different cycles was performed according to established criteria $[18,19]$. Briefly, proestrus is characterized by a predominance of nucleated epithelial cells and estrus by anucleated, cornified epithelial cells. Metestrus is characterized by an equal portion of nucleated or anucleated epithelial cells and leukocytes, while diestrus is characterized by a predominance of leukocytes. Blood samples were collected from the tail vein, using Li heparin tubes (BD Microtainer, New Jersey, USA) and centrifuged at $3000 \mathrm{rcf}$ $\left(1.12 \mathrm{R}(\mathrm{RPM} / 1000){ }^{2}\right.$ ) for $5 \mathrm{~min}$. Sera and plasma were harvested and stored at $-20 \mathrm{C}$. Samples were collected at 9:00 am before the first injection of buserelin or saline (day 0 ), in the fourth session of injections (day 0 and 5), and at sacrifice. Vaginal smears and blood samples taken on day 0 , before the first injection, served as an individual control for each rat.

\section{Tissue preparation}

The gut segments and the uteri were opened and embedded, flattened, in filter paper. One portion of each gut segment was fixed in Stefaninis fixative (a mixture of $2 \%$ formaldehyde and $0.2 \%$ picric acid in phosphate buffer, $\mathrm{pH}$ 7.2) for $22 \mathrm{~h}$ at $4 \mathrm{C}$, and the other portion and the uteri were fixed in $4 \%$ paraformaldehyde in $0.1 \mathrm{M}$ phosphate buffer for $22 \mathrm{~h}$ at $4 \mathrm{C}$. Stefanini-fixed 
specimens were rinsed three times in Tyrodes solution containing 10\% sucrose, before being orientated and mounted for longitudinal- and cross-sectioning in TissueTek (Sakura, Histolab, Gothenburg, Sweden), frozen on dry ice, and sectioned $(10 \mu \mathrm{m})$. Paraformaldehyde-fixed specimens were dehydrated in ethanol, cleared in xylene, orientated for longitudinal- and cross-sectioning, embedded in paraffin, and sectioned $(5 \mu \mathrm{m})$. Sections were processed for immunocytochemistry and histochemistry.

\section{Histochemistry}

Measurements of wall layer thickness were performed on deparaffinized, hydrated, and hematoxylin-eosin-stained paraffin sections from the uterus by using a computerized, image-analyzing system (Imagescope, Aperio ScanScope GL SS5082, Vista, CA 92081, USA). The myometrial thicknesses to be measured were indicated manually, and then measured using a computerized binary cursor. Mean values of 610 representative measurements were calculated from each rat.

\section{Immunocytochemistry}

For studies on enteric neuronal survival, antibodies against human neuronal protein $\mathrm{HuC} / \mathrm{D}(\mathrm{HuC} / \mathrm{D})$ were used as the general neuronal marker. Paraffin sections were deparaffinized, hydrated, and subjected to antigen retrieval by boiling in citrate acid buffer ( $0.01 \mathrm{M}, \mathrm{pH}$ 6) in a microwave oven $(650 \mathrm{~W})$ for $27 \mathrm{~min}$. The sections were cooled and washed in distilled water followed by phosphate-buffered saline (PBS)/Triton. Sections were exposed to biotinylated, primary antibodies against $\mathrm{HuC} / \mathrm{D}$ at $4 \mathrm{C}$ overnight. For visualization of biotinylated $\mathrm{HuC} / \mathrm{D}$, a VECTASTAIN $A B C$ kit containing horseradish peroxidase (HRP) and 3,3 -diaminobenzidine tetrahydrochloride (DAB) was used (Vector Laboratories, Inc., CA, USA). HuC/D-immunoreactive neurons stained dark brown and were counted in submucous and myenteric ganglia on longitudinally-cut sections using a computerized, image-analyzing system (Imagescope). The number of HuC/D neurons in colon was counted in scanned sections in a total length of at least $30 \mathrm{~mm}$, cut at 69 different depths per region and rat. Synthetic antigens for testing the specificity of antibodies against $\mathrm{HuC} / \mathrm{D}$ are not commercially available. Thus, omission of the primary antibodies was used as controls. Results are expressed as numbers of submucous or myenteric neurons, immunoreactive to $\mathrm{HuC} / \mathrm{D}$, per mm length of GI tract.

To study whether the neuronal loss was general or specific regarding the subpopulations of enteric neurons, the relative numbers of different subpopulations were studied in colon, as this was the most affected region in the former study [4]. Antibodies against CGRP, CART, galanin, GRP, NPY, NOS, 5-HT, somatostatin, SP, VIP, in combination with antibodies against $\mathrm{HuC} / \mathrm{D}$, were used on cryo sections. Since vesicular acetylcholine transporter (VAchT) immunoreactivity is mainly located on nerve fibers, antibodies against VAchT alone, and not in combination with $\mathrm{HuC} / \mathrm{D}$, were used on cryosections. Details on the antibodies are given in Table 1. Absorption controls were performed by adding an excess amount of antigen $\left(\begin{array}{lll}10 & 100 \mu \mathrm{g}\end{array}\right.$ of synthetic peptide diluted in antiserum) before exposure.

The sites of the antibody-antigen reactions were visualized by exposure to a mixture of DyLight TM 488conjugated goat anti-mouse IgG serum and Alexa Fluor TM 594-conjugated donkey anti-rabbit IgG serum, or solely to Texas red donkey anti-goat (all diluted 1:1000; Jackson ImmunoResearch Laboratories, Inc., Novakemi AB, Handen, Sweden), for $1 \mathrm{~h}$ in room temperature (RT) and then mounted in phosphate buffer:glycerol 1:1.

$\mathrm{HuC} / \mathrm{D}$-immunoreactive neurons also immunoreactive to NOS, 5-HT or any of the neuropeptides tested, were evaluated in cross- and longitudinally-cut, whole-wall sections. At least 150 submucous neurons and 250 myenteric neurons were counted for each set of double-stains and rat. The results are expressed as the percentage of $\mathrm{HuC} /$ D-immunoreactive neurons also immunoreactive to NOS, 5-HT or any of the neuropeptides. Since VAchT immunoreactivity is mainly located on nerve fibers, the relative number of VAchT-immunoreactive nerve cell bodies could not be evaluated. Nerve fiber density was evaluated on a $0,(+),+,++,+++$ scale, where 0 indicates no fibers, $(+)=$ occasional fibers, $+=$ few fibers, $++=$ moderate num bers of fibers, and $+++=$ numerous fibers.

\section{Studies on gastrointestinal function}

To measure total GI transit time, the rats fasted overnight by removing their food at 9:00 pm. At 9:00 am the next day, the rats were given a bolus dose $(1 \mathrm{ml})$ of carbon suspension trough gavage administered orally to the stomach (150 mg/ml, Abigo Medical, Gothenburg, Sweden) before being placed in separate cages with free access to food and water. The rats were continuously and manually monitored by staff being present all the time, until the first carbon-containing fecal pellets were seen to be excreted.

In order to study fecal weight and fecal content [30], feces were collected and weighed from all rats during the $12 \mathrm{~h}$ of fasting, prior to the measurement of GI transit time, see above. The fecal samples were kept in open glass tubes and left to dry at RT for 3 months in a fume cupboard. The dry feces were ground in a mortar, transferred to a $20 \mathrm{ml}$ glass vial, and weighed. To extract the fat from the feces, $10 \mathrm{ml}$ of dichloromethane (DCM, Chromasolv, Sigma-Aldrich, Stockholm, Sweden) was added. The mixture was stirred vigorously for $1 \mathrm{~h}$ at RT. The DCM phase was filtered with a plastic syringe $(10 \mathrm{ml})$, fitted with a polyethylene frit $(20 \mu \mathrm{m}, 10 \mathrm{ml}$, Biotage, Uppsala, Sweden) and a syringe filter $(1 \mu \mathrm{m}$, Acrodisc glass fiber, Pall, NY, USA), and collected in a pre-weighed glass vessel. The extraction procedure was repeated twice for a total of $30 \mathrm{ml}$ 
Table 1 Details on antibodies

\begin{tabular}{|c|c|c|c|c|c|}
\hline Raised against & Code no. & Host & $\begin{array}{l}\text { Working dilution } \\
\text { cryosections }\end{array}$ & Supplier & References \\
\hline CART (61 102) & $\mathrm{H}-003-61$ & Rabbit & $1: 5000$ & Phoenix, GmBH, USA & $\begin{array}{l}\text { Ekblad et al. 2003; } \\
\text { Zacharko-Siembida et al. } 2014 \text { [20,21] }\end{array}$ \\
\hline CGRP & 8427 & Rabbit & $1: 5000$ & Euro-Diagnostica, Sweden & Ekblad et al. 1998 [8] \\
\hline Galanin & 8416 & Rabbit & $1: 1000$ & Euro-Diagnostica, Sweden & Ekblad et al. 1988; Ekblad et al. 1998 [8,22] \\
\hline GRP & R-6902 & Rabbit & 1:640 & & Ekblad et al. 1988 [22] \\
\hline $\begin{array}{l}\text { Hu proteins } \\
\text { (HuC/HuD) }\end{array}$ & A-2127 & Mouse & 1:600 & Life Technologies, USA & Lin et al. 2003 [23] \\
\hline NOS & 9223 & Rabbit & $1: 5000$ & Euro-Diagnostica, Sweden & Ekblad et al. 1994; Kristensson et al. 2007 [24,25] \\
\hline C-PON* & CA-08-300 & Rabbit & $1: 3000$ & Genosys, UK & Ekblad et al. 1988; Kristensson et al. 2007 [22,25] \\
\hline Serotonin $(5-H T)$ & NSER & Rabbit & $1: 1200$ & Inc. Star Corp, USA & Mulder et al. 1997 [26] \\
\hline Somatostatin & 1758 & Rabbit & $1: 3200$ & Kind gift from prof. J.J. Holst, Denmark & Ekblad et al. 1988; Kristensson et al. 2007 [22,25] \\
\hline Substance P (SP) & SP7 & Rabbit & $1: 800$ & Kind gift from prof. Emson, UK & Lindestrm et al. 2002 [ 27] \\
\hline VIP & 7854 & Rabbit & $1: 2000$ & Euro-Diagnostica, Sweden & Qian B et al. 2001; Kristensson et al. 2007 [25,28] \\
\hline VAchT & $A B 1578$ & Get & $1: 2000$ & Chemicon, USA & Arvidsson U et al., 1997 [29] \\
\hline
\end{tabular}

${ }^{*}$ C-terminal flanking peptide of NPY (used for the detection of NPY-containing neurons).

of the DCM phase. When executing the last extraction, the solid material and the DMC were transferred to the syringe. To ensure that as much as possible of the organic solvent was filtered into the glass vessel, a plunger was used to squeeze the solid material. The solvent was removed by evaporation and the residue (fat content) was weighed.

In order to study the absorptive capacity of galactose after $12 \mathrm{~h}$ of fasting, a bolus dose of $1 \mathrm{ml}$ of $5 \%$ galactose dissolved in saline was given via a stomach tube as an oral bolus dose under anesthesia. Blood samples were collected in Li Heparin tubes from the tail vein using a neoflon catheter, before and $10 \mathrm{~min}, 30 \mathrm{~min}$, and $90 \mathrm{~min}$ after the bolus dose [31]. Galactose levels in plasma were analyzed with a BioVisions Galactose Assay Kit (K621100, BioVision Incorporated, CA, USA) according to the manufacturers protocol. Briefly, galactose is oxidized using a galactose probe, an enzyme mix, and HRP, generating a colored product analyzed at the optic density of $570 \mathrm{~nm}$.

\section{Serum analyses}

Analyses of IgM- and IgG antibodies in serum against GnRH, GnRH receptor (GnRHR), LH, and LH receptor (LHR) were carried out in blood samples collected at sacrifice by an enzyme-linked immune sorbent assay (ELISA) as described in detail previously [3]. Briefly, the wells of microtiter plates (456537 Nunc, Roskilde, Denmark) were either coated with human $\mathrm{GnRH}$ or N-terminal GnRH-R peptide ((NH2)-ANSASPEQNQNHCSAINN SIPLMQGNLPY) conjugated with ovalbumin (OVA) (Innovagen, Lund, Sweden), $100 \mathrm{ng} /$ well, in an overnight incubation at $4 \mathrm{C}$. Thereafter, the plastic wells were blocked with $0.5 \%$ bovine serum albumin (BSA) (A-7030, Sigma, St Louis, USA) in PBS (10 $\mathrm{mM} \mathrm{PO}_{4}{ }^{3-}$, $137 \mathrm{mM} \mathrm{NaCl}$, and $2.7 \mathrm{mM} \mathrm{KCl}, \mathrm{pH} 7.4)$ containing $0.05 \%$ Tween-20 (PBS-T). The dilutions of patient serum (1:400 in $1.0 \mu \mathrm{g}$ OVA (A-5503, Sigma)/ml 0.5\% BSA in PBS-T) or mouse anti-human GnRH antibody $(1.11 \mathrm{mg} /$ ml, ab62432, Abcam, Cambridge, MA, USA) in serial dilution (1:2 000 1:32 000 to construct a standard curve) or rabbit anti-human GnRHR antibody (90217.09, Innovagen) in serial dilution (1:8 000 1:128 000) were then added to the plates and incubated for $2 \mathrm{~h}$ at RT. After rinsing with PBS-T, deposition of antibodies directed to $\mathrm{GnRH}$ or GnRHR was detected using the secondary antibodies rabbit anti-rat IgG-biotin (ABCAM102170, Abcam, Cambridge, MA, USA) or goat anti-rat IgM-biotin (ABCAM97178, Abcam) diluted 1:10 000 in PBS-T.

Analysis of antibodies against LH was carried out with intact, purified, native human LH (MBS537383, MyBiosource, San Diego, CA, USA), 100 ng/well, in PBS or only PBS-T (to provide an internal blank). After overnight incubation at $4 \mathrm{C}$, the plates were washed three times with PBS-T and blocked with $0.5 \%$ BSA in PBS-T. Dilutions of serum (1:200) from patients and blood donors, or rabbit anti-human LH antibody (MBS535386, MyBiosource) in serial dilution (to construct a standard curve), with BSA in PBS-T were then added to the plates in triplicate (two wells coated with $\mathrm{LH}$ and one well coated with PBS-T) and incubated for $2 \mathrm{~h}$ at RT. The washing procedure was repeated and deposition of autoantibodies directed to $\mathrm{LH}$ was detected using secondary antibodies as described above, appropriately diluted in PBS-T.

Analysis of antibodies against the LHR was carried out with the N-terminal LHR peptide ((NH2)-MKQRFSSALQL 
LKLLLLQPPLPRALC), conjugated with OVA (Innovagen), in $100 \mathrm{mM}$ Carbonate buffer pH 9.2 or only Carbonate buffer (to provide an internal blank). After overnight incubation at $4 \mathrm{C}$, the plates were washed three times with PBS-T and blocked with 0.5\% BSA in PBS-T. Dilutions of serum (1:200) from patients and blood donors with BSA in PBS-T were then added to the plates in triplicate, two to LHR and one to Carbonate buffer-coated wells, and incubated for $2 \mathrm{~h}$ at RT. The washing procedure was repeated and deposition of autoantibodies directed to LHR was detected using secondary antibodies as described above, appropriately diluted in PBS-T.

The absorbance at $405 \mathrm{~nm}$ was measured after $30 \mathrm{~min}$ of incubation at RT. Antibody levels are expressed as arbitrary units (AU) (absorbance values after subtracted background levels and multiplied with 1000).

\section{Plasma analyses}

Due to the small amount of rat plasma, all analyses were performed with a single sample. Samples were analyzed according to the manufacturers instructions, and the resulting color changes were measured at the optical density of $450 \mathrm{~nm}$. Each sample was interpolated from the standard curve.

Follicle-stimulating hormone (FSH)-, 17 $\beta$ estradiol (E2)-, and LH ELISA kits (MBS720215, MBS162143 and MBS161787, respectively, MyBiosource, San Diego, CA, USA) based on the double antibody sandwich technology were used in plasma samples collected at study start and during session 4. Plates were pre-coated with monoclonal antibodies selectively recognizing rat FSH, E2 or LH. Standards of FSH: 2.5, 5.0, 10, 25, and $50 \mathrm{ng} / \mathrm{ml}$; E2: 30, 60, 120, 240, and $480 \mathrm{ng} / \mathrm{l}$; and LH: 31.2, 62.5, 125, 250, 500, and $1000 \mathrm{ng} / \mathrm{ml}$ (to form a standard curve) or undiluted rat heparin plasma samples were then added to the wells on a microtiter plate (Nunc). A standardized preparation of immune complexes in the form of HRP-conjugated polyclonal antibody (FSH), or antibodies labeled with biotin/streptavidin HRP (E2 and LH), were added.

A rat zonulin ELISA kit (MBS753035, MyBiosource) based on the competitive enzyme immunoassay technique was used to study epithelial integrity in plasma harvested at sacrifice. The standards of $25,50,100,250$, and $500 \mathrm{ng} / \mathrm{ml}$, undiluted rat heparin plasma, and buffer were incubated together with zonulin HRP conjugate on a plate pre-coated with monoclonal anti-zonulin antibodies.

\section{Statistical analyses}

All results are presented as medians (interquartile ranges (IQR)), except weight, which is presented as mean standard error of the mean (SEM). Statistical analyses were performed by using the Mann Whitney $U$-test. $\mathrm{P}<0.05$ was considered statistically significant.

\section{Results}

\section{General characteristics}

One rat in each group was terminated because of administration to the lung of the oral galactose solution, leaving 11 buserelin-treated (B) rats and seven saline-treated control (C) rats for the analyses. The body weight gain increased transiently in buserelin-treated rats in week 5 and 9 ( $p<0.001$; see Additional file 1). These time points coincided with the end of the buserelin sessions 2 and 3 . The plasma levels of FSH were extremely low or undetectable in all rats (data not shown). The LH kit was unusable on rat plasma and serum, as no standard curve could be constructed. The estradiol levels in plasma were in the same range at start (Day 0, session 1; C = $52\left(\begin{array}{ll}41 & 62\end{array}\right) \mathrm{ng} / \mathrm{L}$, $\mathrm{B}=55$ (46 58) $\mathrm{ng} / \mathrm{L}$ ), but during session 4 , they were elevated on day 0 and 5 in the buserelin-treated group, reflecting that the hypothalamus-hypophys-gonadal axis was not suppressed by buserelin treatment in this setting $(\mathrm{p}<0.05$; for details see Additional file 2). At start (day 0, session 1), the vaginal smears indicated that all rats were unsynchronized in their estrus cycle (12 buserelin-treated and eight saline-treated controls). After the first week of treatment, the saline-treated rats were still unsynchronized, while the buserelin-treated rats were all in metestrus or diestrus. In the fourth week of injection treatment, the saline-treated rats were still unsynchronized on day 0 and 5 , while the buserelin-treated rats were all in metestrus on day 0 and in diestrus on day 5 (see Additional file 3). The uterine muscle layer was thicker in the group of buserelin-treated rats compared to saline-treated controls $(\mathrm{p}<0.05$; see Additional file 4$)$.

\section{Neuronal loss and neuronal subpopulations}

Significant reductions in the absolute numbers of submucous neurons were detected in ileum and colon (27\%, $\mathrm{p}<0.05$ and $61 \%, \mathrm{p}<0.05$, respectively). Of the myenteric neurons, reduced numbers were noted in the stomach $(27 \%, \mathrm{p}<0.05)$, ileum $(39 \%, \mathrm{p}<0.01)$, and colon $(31 \%, \mathrm{p}<$ 0.01 . The loss of neurons was statistically more pronounced in myenteric than in submucous ganglia, and more pronounced in the colon and ileum than in the stomach (Figure 1; for raw data see Additional file 5).

In colon, a small number (fewer than 10\%) of submucous nerve cell bodies were immunoreactive to CGRP, CART, galanin, NPY or SP, while GRP-, NOS-, and VIP immunoreactivity were found in $10 \% 43 \%$ of submucous neurons. The relative number of somatostatin-immunoreactive submucous nerve cell bodies was $11 \%$ in colon from controls, but showed a tendency to increase to $14 \%$ after buserelin treatment ( $p=0.062$; Figure 2; for raw data see Additional file 5). In both controls and buserelin-treated rats, few colonic myenteric nerve cell bodies were found to contain CGRP-, galanin-, NPY-, SP-, or VIP immunoreactivity, and moderate numbers of neurons were found to contain 


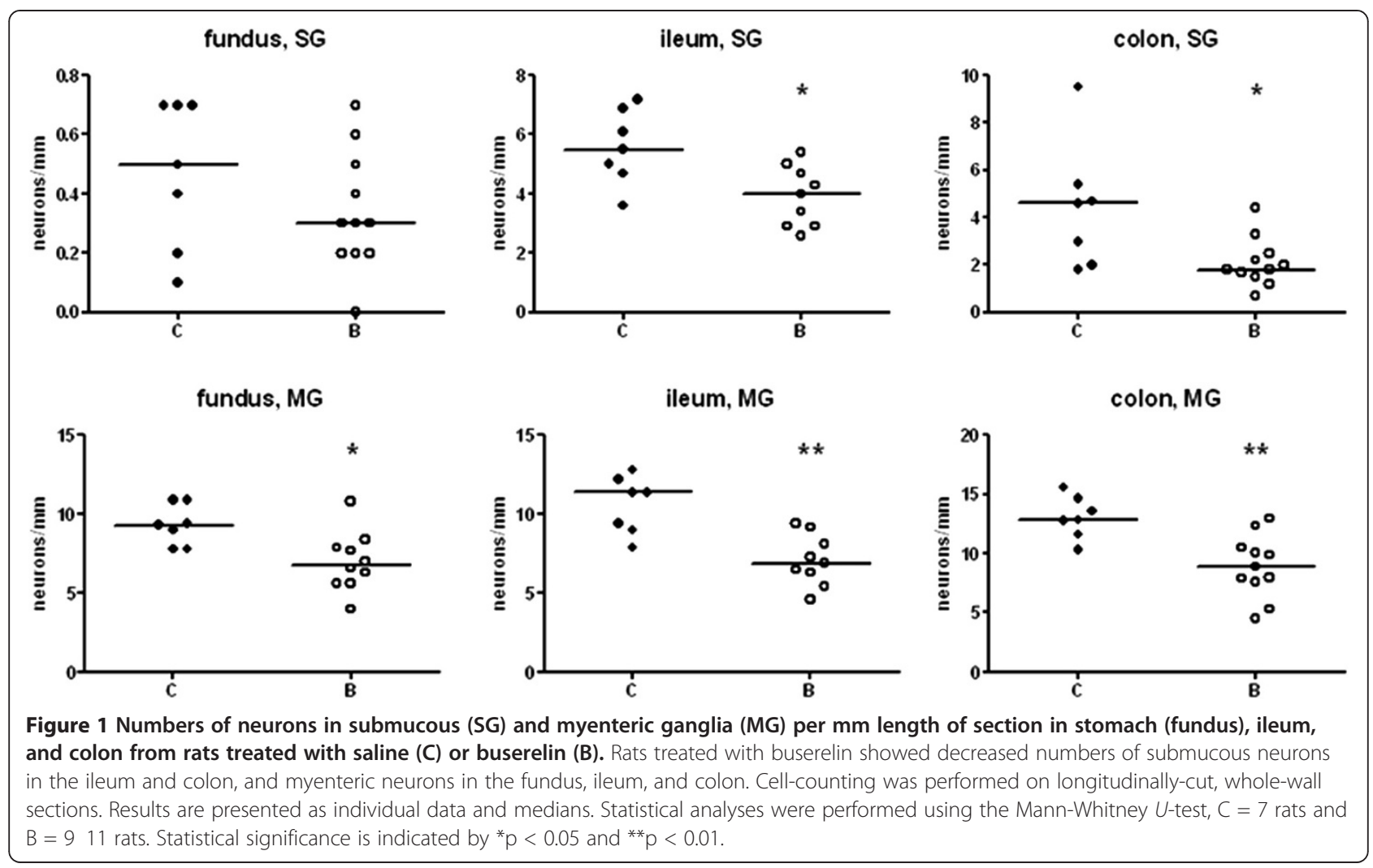

CART, GRP, and somatostatin, whereas myenteric NOS immunoreactivity was abundant (Figure 2). Nerve cell bodies immunoreactive to 5 -HT was not detected, but a sparse network of nerve terminals was found in the mucosa and myenteric ganglia. The nerve fiber density was not affected by buserelin treatment in any of the neuronal subpopulations studied (Table 2). Pictures of immunostainings of NOS and neuropeptides studied are shown in Figure 3.

\section{Studies on gastrointestinal function}

Total feces weight decreased in buserelin-treated animals, whereas total fat content per gram dried feces increased, compared to control rats (Figure 4a and b; for raw data see Additional file 5).

There was no difference in the total GI transit time between the buserelin-treated and the control rats, but a large spread of individual values was noted within the buserelintreated group (Figure 5a). The area under the curve (AUC) of absorbed galactose did not differ between the two groups, but again, a large spread of individual values was noted within the buserelin-treated group (Figure $5 \mathrm{~b}$ ).

Low titers of antibodies against GnRH, GnRHR, LH, and LHR were found in serum in both groups (Figure 6a and b). Plasma levels of zonulin were similar in both groups $(\mathrm{C}=41$ (32 49) $\mathrm{ng} / \mathrm{ml} ; \mathrm{B}=34$ (33 38$) \mathrm{ng} / \mathrm{ml})$.

\section{Discussion}

The present study confirms previous findings of a marked loss of enteric neurons (27\% 61\%) in rat appearing soon after buserelin administration [4], with a tendency of increased relative number of somatostatin-immunoreactive submucous neurons. Buserelin caused increased estradiol levels in plasma and thickened uterine muscle layers, indicating high estrogen activity. Furthermore, the study revealed that buserelin-treated rats had a decreased feces weight with higher fat content, compared to controls. In view of the marked buserelin-induced loss of enteric neurons, the differences between buserelin-treated rats and controls were surprisingly modest in the physiological parameters investigated. The neuronal loss described previously was most pronounced in colon [4], but in the present study, the neuronal loss was the same in ileum as in colon.

All rats had free access to food and water, except during two short fasting periods. The decreased feces weight after buserelin treatment is not easily explained by dehydration, changed food intake or cachexia, as the body weight was unaltered. Secretion of intestinal fluid is regulated mainly by submucous ganglia [32]. The tendency to relative increase in the number of submucous somatostatin neurons seen in the present study might affect intestinal secretion, since these most likely are cholinergic secretomotor 

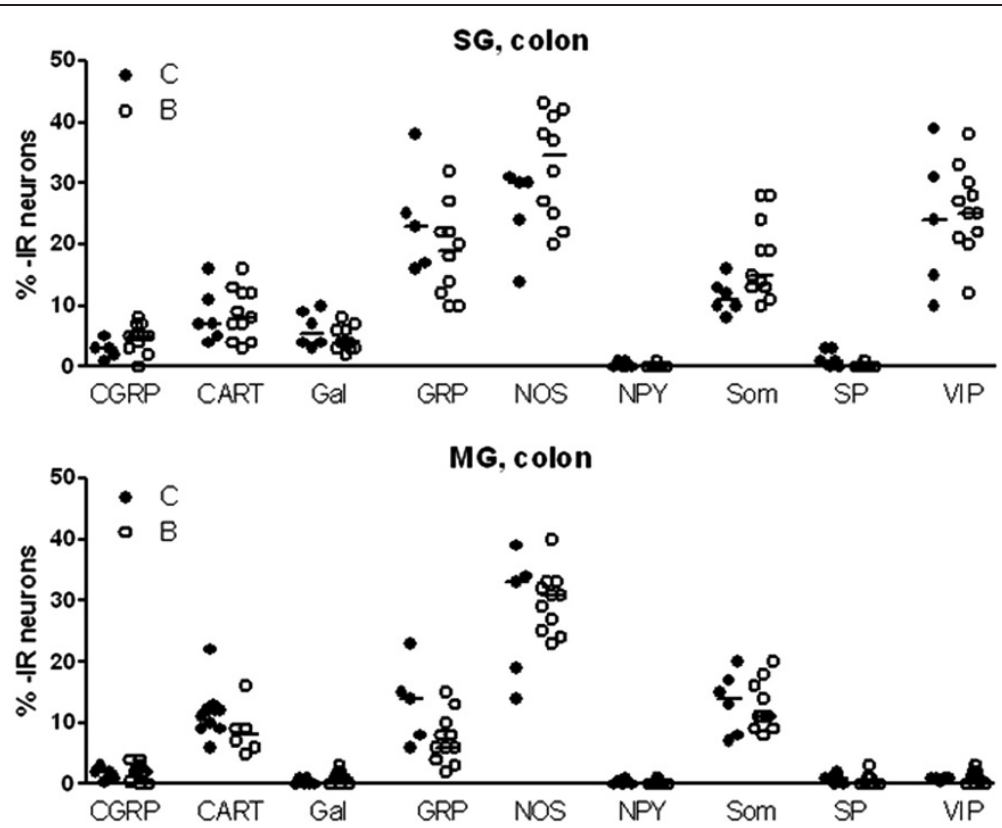

Figure 2 Relative numbers of immunoreactive neurons in submucous (SG) and myenteric (MG) ganglia in colon for calcitonin gene-related peptide (CGRP), cocaine- and amphetamine-related transcript (CART), galanin (Gal), gastrin-releasing peptide (GRP), neuropeptide Y (NPY), nitric oxide synthase (NOS), somatostatin (som), substance P (SP), and vasoactive intestinal peptide (VIP), expressed as \% of human neuronal protein HuC/D-immunoreactive neurons, from rats treated with four sessions of saline (C) or buserelin (B). Cell-counting was performed on cross- and longitudinally-cut, whole-wall cryo sections, doubly immunostained for HuC/D and respective neuropeptide or NOS. With the exception of submucous som-immunoreactive neurons, which showed a tendency to increase after buserelin treatment $(p=0.062)$, no differences in any of the neuronal subpopulations were found between groups. Results are presented as individual data and medians. Statistical analyses were performed by the Mann-Whitney $U$-test, $C=56$ rats and $B=1011$ rats.

neurons, also containing CGRP, issuing projections both orally and anally to the mucosa and submucosa [6,33]. Increased somatostatin inhibitory input could lead to reduced secretomotor activity, leading to reduced fluids in the lumen and feces, affecting fecal water content and fecal weight.

The most plausible explanation for the higher percentage of fat in the feces of buserelin-treated rats is maldigestion and/or malabsorption of dietary fat. The regulatory mechanisms of digestion and absorption of fat are complex, with several neural short and long reflexes involving an intricate synchronization of intestinal motility and secretion, gallbladder contraction, exocrine pancreas secretion, and hormone release from endocrine cells. An intact neural function is crucial for the regulation of gut peptide secretion from endocrine cells, and for emptying of bile and pancreatic enzymes into the intestinal lumen [34,35].

In the present study, no increase of the relative numbers of VIP- or NOS-immunoreactive neurons were found, when the rats were euthanized 2 weeks after the end of

Table 2 Nerve fiber density and distribution in colon was identical in saline- and buserelin-treated rats

\begin{tabular}{llllllllllll}
\hline & CGRP & CART & Gal & GRP & NPY & NOS & 5-HT & Som & SP & VIP & VAchT \\
\hline M & $(+)$ & ++ & ++ & ++ & ++ & + & $(+)$ & + & $(+)$ & +++ & $(+)$ \\
SM & $(+)$ & + & ++ & ++ & +++ & + & 0 & + & $(+)$ & +++ & $(+)$ \\
SG & + & ++ & $+++(+)$ & +++ & ++ & ++ & 0 & + & $(+)$ & +++ & + \\
MG & + & +++ & +++ & +++ & ++ & +++ & + & + & ++ & ++ & ++ \\
CM & $(+)$ & +++ & $+(+)$ & + & ++ & $+++(+)$ & 0 & $(+)$ & $(+)$ & ++ & $(+)$ \\
LM & $(+)$ & + & $(+)$ & + & ++ & + & 0 & $(+)$ & $(+)$ & + & + \\
BV & $(+)$ & $(+)$ & 0 & 0 & +++ & $(+)$ & 0 & + & 0 & $(+)$ & 0 \\
\hline
\end{tabular}

The colon mucosa (M), submucosa (SM), submucous ganglia (SG), myenteric ganglia (MG) circular (CM) and longitudinal (LM) muscle layers, and blood vessels (BV) were evaluated separately. The density and distribution of nerve fibers immunoreactive to calcitonin gene-related peptide (CGRP), cocaine- and amphetamine-related transcript (CART), galanin (Gal), gastrin-releasing peptide (GRP), neuropeptide Y (NPY), nitric oxide synthase (NOS), serotonin (5-HT), somatostatin (Som), substance P (SP), vasoactive intestinal peptide (VIP), and vesicular acetylcholine transporter (VAchT) in colon of saline- and buserelin-treated rats are shown combined as no differences in nerve fiber density and distribution were found between groups. Nerve fiber density was evaluated on a $0,(+),+,++,+++$ scale, where 0 indicates no fibers, $(+)=$ occasional fibers, $+=$ few fibers, $++=$ moderate numbers of fibers, and $+++=$ numerous fibers. $n=511$. 


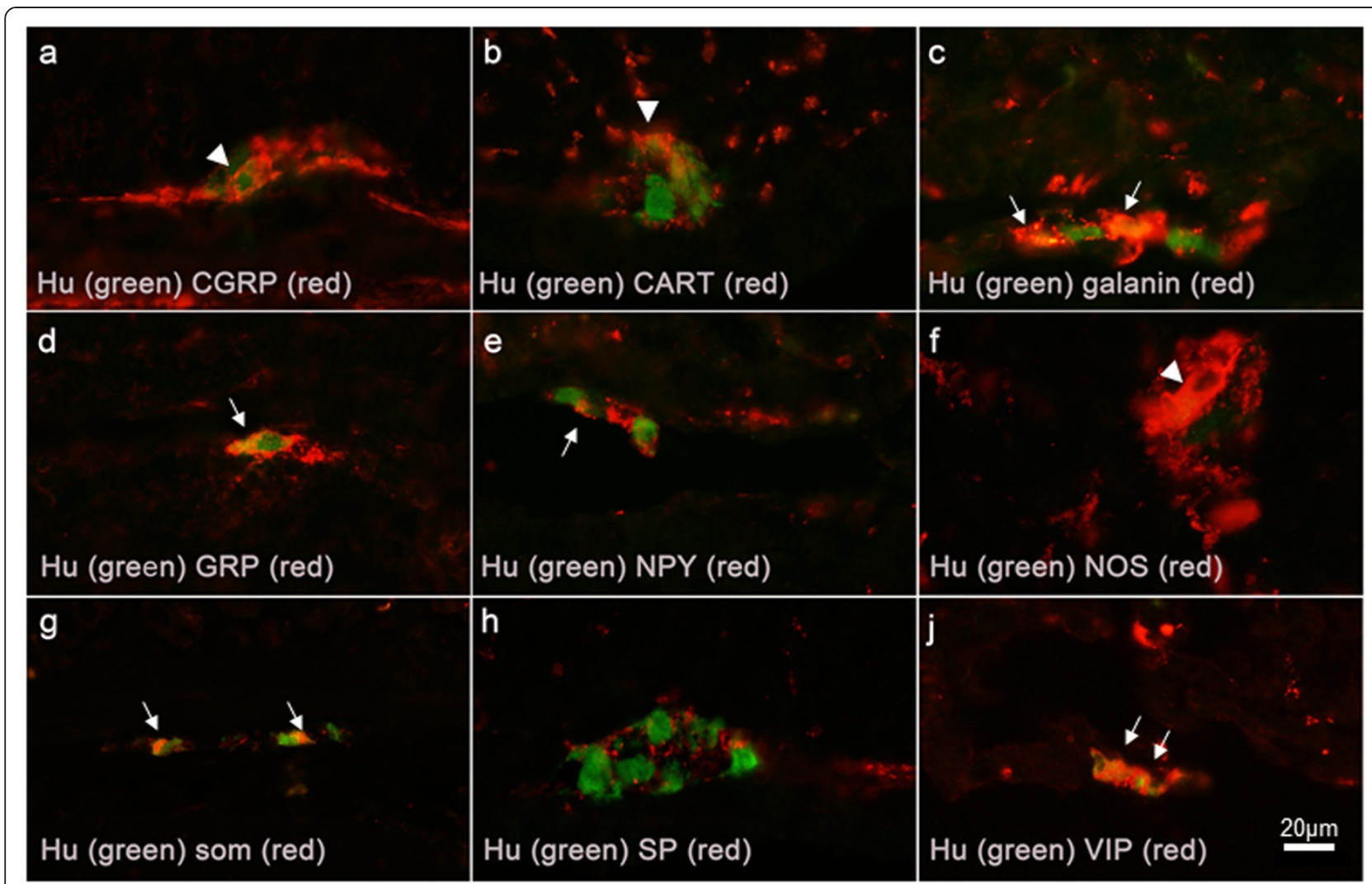

Figure 3 Cryo sections of colon from rats treated with saline $(b, c, e, g, j)$ or buserelin $(a, d, f, h)$ immunostained with human neuronal protein HuC/D (green) and calcitonin gene-related peptide (CGRP), cocaine- and amphetamine-related transcript (CART), galanin, gastrin-releasing peptide (GRP), neuropeptide Y (NPY), nitric oxide synthase (NOS), somatostatin (som), substance P (SP), and vasoactive intestinal peptide (VIP)(red). Micrographs are merged and show intense immunostaining, irrespective of treatment. Arrowheads indicate HuC/D-immunoreactive myenteric neurons also immunoreactive to CGRP (a), CART (b), and NOS (f). Arrows indicate a HuC/D-immunoreactive submucous neuron also immunoreactive to galanin (c), GRP (d), NPY (e), som (g), and VIP (j). In micrograph (h), SP-immunoreactive fibers innervate a myenteric ganglia. Scale bar $=20 \mu \mathrm{m}$ applies for all the micrographs in Figure 3 .

the fourth session. In our previous study of colon, a significant increase of myenteric VIP-containing neurons was found after two sessions of buserelin treatment, and in both submucous and myenteric NOS-immunoreactive neurons after four sessions of treatment, when rats were euthanized immediately after the fourth treatment [4].
This suggests that 2 weeks post treatment, the acute neuronal/tissue impingement has subsided, since increased expression of VIP and NOS are early signs of an injurious event, e.g. lipopolysaccharide (LPS) challenge, axotomy or after ischemia followed by reperfusion $[7,10,11]$. In general, the relative numbers of neurons immunoreactive to

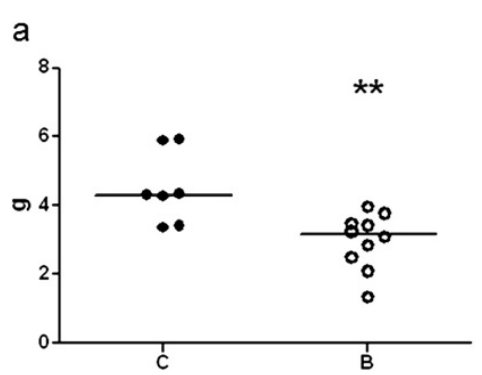

b

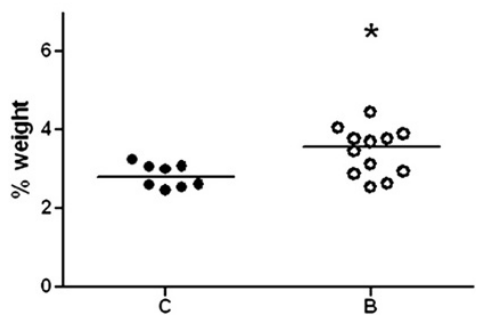

Figure 4 Fecal weight (a) and fecal fat (b) in saline (C)- and buserelin (B)-treated rats. Feces were collected and weighed after $12 \mathrm{~h}$ of fasting. Feces from buserelin-treated rats had a lower weight (g) compared to feces from saline-treated rats. Fecal fat was analyzed on dried feces. Buserelin-treated rats had an increased weight percentage of fat in feces compared to saline-treated rats. Results are presented as individual data and medians. Statistical analyses were performed by the Mann-Whitney U-test, $C=78$ and B $=1012$ rats. Statistical significance is indicated by ${ }^{*} p<0.05$ and ${ }^{* *} p<0.01$. 

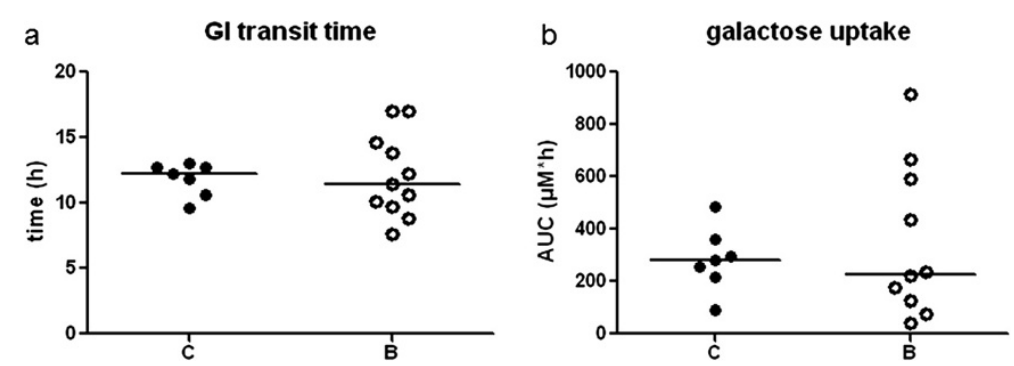

Figure 5 Gastrointestinal (GI) transit time (a) and total concentration of absorbed galactose ( $\mu M^{*} h$, area under curve (AUC)) (b) in saline (C)- and buserelin (B)-treated rats. No difference in total Gl transit time was noted (a). The AUC of galactose in plasma did not differ between the two groups (b). Results are presented as individual data and medians. Statistical analyses were performed by using the Mann-Whitney U-test, $C=7$ and $B=11$ rats.

CGRP, CART, galanin, GRP, NPY, NOS, 5-HT, SP, VIP or VAchT, and their nerve fiber density, were unaffected by buserelin treatment. This implies that the neuronal loss is nonselective to subpopulations. It also strengthens the concept that ENS is highly adaptive and strives to maintain its original set of neuronal subpopulations, as well as its distribution and density of nerve terminals.

Although the enteric neuronal loss was most pronounced in the myenteric ganglia, the GI transit time and galactose absorption were generally not affected by repeated buserelin treatments. A greater inter-individual difference was seen in buserelin-treated rats, in analogy to the inter-individual effect on GI function observed in women after treatment with a GnRH analog $[2,3,36]$. The transport protein called sodium-glucose transport protein 1 (SGLT-1) is used by enterocytes to absorb both galactose and glucose, and the glucose transporter protein (GLUT2) is located basally for export $[37,38]$. The absorption of nutrients is a vital mechanism depending mainly on the function and integrity of the intestinal mucosa, while intestinal innervation plays a minor role, probably explaining the lack of effect on absorption in the current study.

Initial administration of a $\mathrm{GnRH}$ analog in man leads to increased secretion of FSH and $\mathrm{LH}$, whereas continuous stimulation leads to receptor desensitization and down-regulation of gonadotropin secretion after 10 days of treatment [39]. The LH secretion in female rats starts in proestrus, peaks in the evening, resulting in ovulation, and shows low levels next morning (estrus). FSH- and LH secretions start simultaneously, but FSH remains elevated throughout the estrus $[40,41]$. The FSH- and LH levels are very low during the rest of the reproductive cycle [41], and are secreted in a pulsatile manner, like GnRH [42]. Although plasma FSH was not measureable in the present study, when the animals were in other cycles than proestrus and estrus, the combination of elevated estradiol levels in plasma, thickened uterine muscle layers, and synchronized reproductive phases in buserelin-treated rats indicate a $\mathrm{GnRH}$ influence on the hypothalamus, leading to enhanced FSH- and LH secretion with ensuing estradiol secretion. From another study, the buserelin-induced loss of enteric neurons is suggested to be mediated via $\mathrm{LH}$ receptor activation, since the relative number of $\mathrm{LH}$ receptor-expressing myenteric neurons was decreased after buserelin treatment, and neither GnRH nor its receptor could be identified in the ENS of the rat [4].

As there was no difference in the prevalence of circulating antibodies against $\mathrm{GnRH}, \mathrm{LH}$, and their receptors between groups, the noted enteric neuropathy is probably not mediated by autoantibodies. GnRH has been found in enteric neurons in man, and the expression of $\mathrm{GnRH}$ antibodies after buserelin-induced dysmotility is probably secondary to the marked neuropathy $[1,2]$, as antibody prevalence and titer were the same before and after buserelin treatment [3]. Alpha- and beta estrogen receptors are expressed in enteric neurons [43], and theoretically, estradiol could exert degenerative effects on the ENS. However, estrogens are widely used in contraceptives and hormonal replacement therapies, without any reports of ensuing dysmotility. The mechanism behind the buserelin-induced neuropathy needs to be further evaluated, for example, in cell culture experiments using primary enteric neurons.

Zonulin participates in the physiological regulation of intercellular tight junctions in the small intestine. Dysregulation of the zonulin pathway may lead to intestinal disorders, and elevated zonulin levels in serum are reported in untreated celiac disease [44]. Similar plasma levels of zonulin in saline- and buserelin-treated rats, as found in the present study, suggest that gut mucosa integrity is mainly uncompromised by the buserelininduced neuropathy.

In the daily clinical work, tests on nutrient absorption and analyses of fat in feces are never or seldom performed. The degree of fat malabsorption can be evaluated, but it is a rough estimation, and is primarily used to reveal exocrine pancreatic insufficiency or severe epithelial dysfunction, e.g. celiac disease. About half of the patients with GI complaints, consulting a gastroenterology ward, are diagnosed as suffering from IBS [45]. The etiology behind IBS 

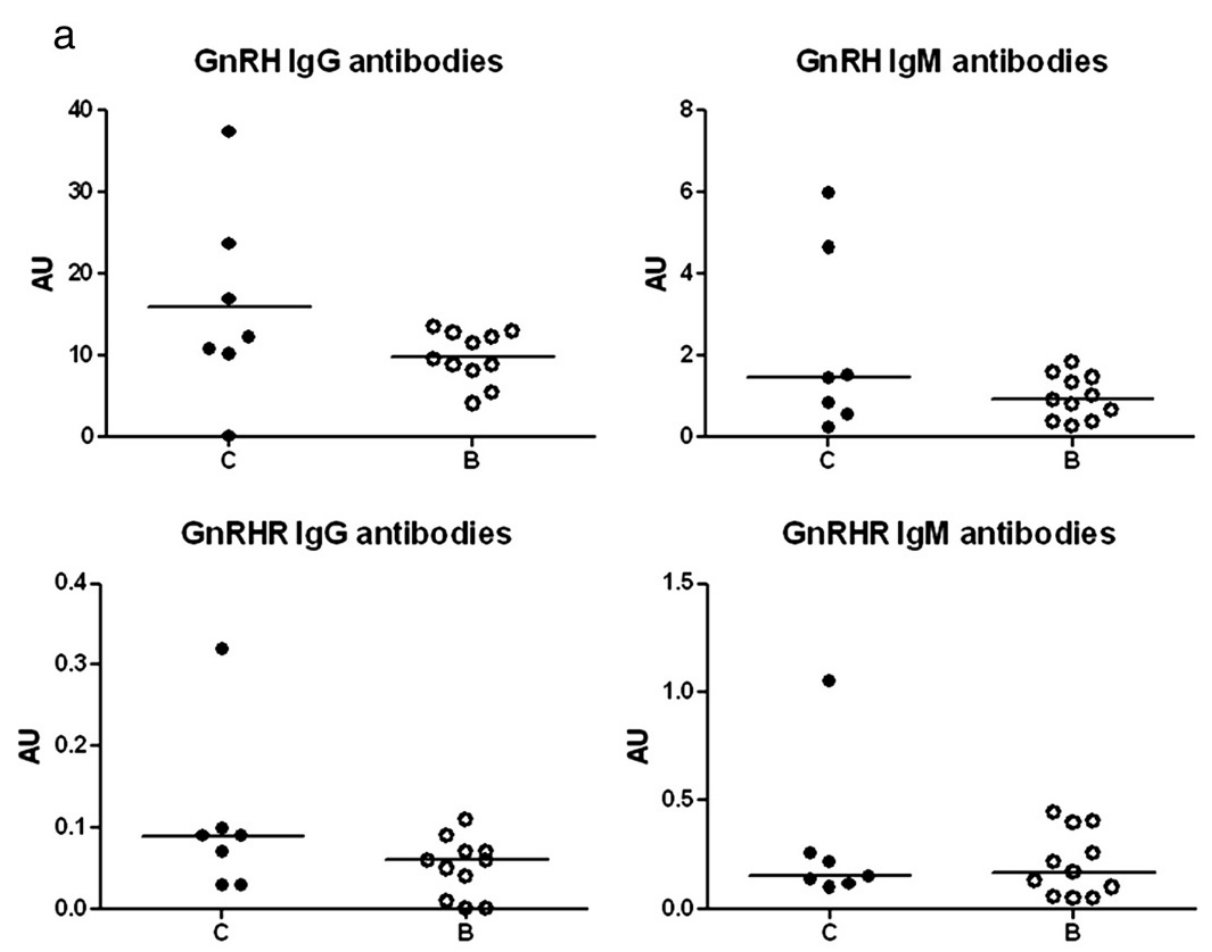

b LH IgG antibodies

\section{LH IgM antibodies}
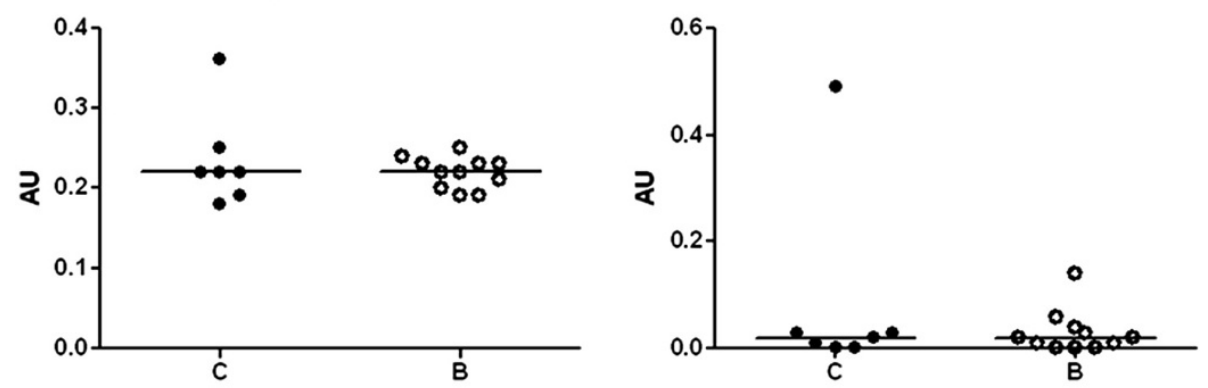

LHR IgG antibodies
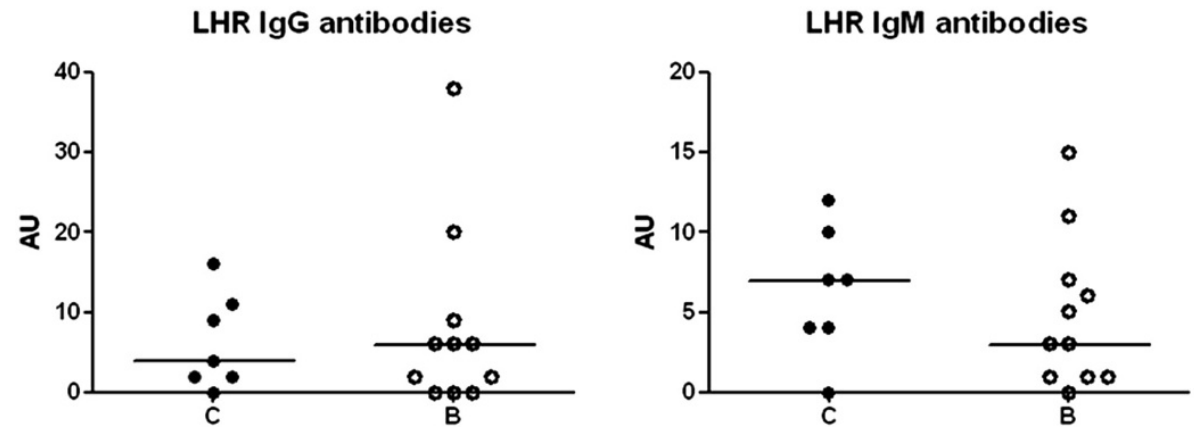

Figure $\mathbf{6}$ Circulating antibodies. a. Circulating lgG- and IgM antibodies against gonadotropin-releasing hormone (GnRH) and its receptor (GnRHR) in saline (C)- and buserelin (B)-treated rats. Low titers (arbitrary units (AU)) of antibodies were found in both saline- and buserelin-treated rats, with no differences between the groups. Results are presented as individual data and medians. Statistical analyses were performed by using the Mann-Whitney U-test, $C=7$ and $B=11$ rats. b. Circulating IgG- and IgM antibodies against luteinizing hormone (LH) and its receptor (LHR) in saline (C)- and buserelin (B)-treated rats. Low titers (arbitrary units (AU)) of antibodies were found in both saline- and buserelin-treated rats, with no differences between the groups. Results are presented as individual data and medians. Statistical analyses were performed by using the Mann-Whitney $U$-test, $C=7$ and $B=11$ rats. 
is uncertain [46], and clinical investigations are unable to reveal objective parameters explaining the dysfunction. Affective disturbances and psychiatric disorders are common, concomitant diagnoses with IBS [45]. Examinations show that IBS patients are associated with an enhanced perception of personal vulnerability to illness [47], and they often over-report symptoms and suffer from somatization disorders $[48,49]$. Functional magnetic resonance imaging (fMRI) reveals significant differences in the neural processing of pain between IBS patients and controls, further underlining the importance of psychological factors in the pathophysiology of visceral hypersensitivity in these patients $[50,51]$. The results in the present study make the possibility feasible that severe, unrevealed enteric neurodegeneration exists in subgroups of IBS patients. Different etiologies for the GI symptoms may explain the difficulties to find conclusive explanations in scientific reports. Chronic abdominal complaints may be a stress factor for the patient, leading to an abnormal central processing of the pain [50,51], and thus, psychological and cognitive dysfunctions in IBS may be secondary, rather than causal. A tendency of an increase in the relative number of somatostatin-immunoreactive submucous neurons was found in our present study. This is interesting since the transient receptor potential vanilloid 1 (TRPV1), which is involved in visceral pain signaling, is up-regulated in IBS patients where it stimulates increased release of somatostatin and SP [52]. Patients who had undergone several IVFs with buserelin treatments suffered from more abdominal pain and exacerbation of IBS 5 years after than prior to treatment, although no obvious dysmotility was found [3]. As the ENS seems to have a huge reserve of functional capacity, the treated patients may acquire a modest, but subclinical, enteric neuropathy making them more vulnerable to complications in, for instance, diabetes mellitus and neurological diseases.

\section{Conclusion}

A marked enteric neuronal loss with modest effects on GI function is found after buserelin treatment. Increased feces fat content is suggested an early sign of dysfunction.

\section{Additional files}

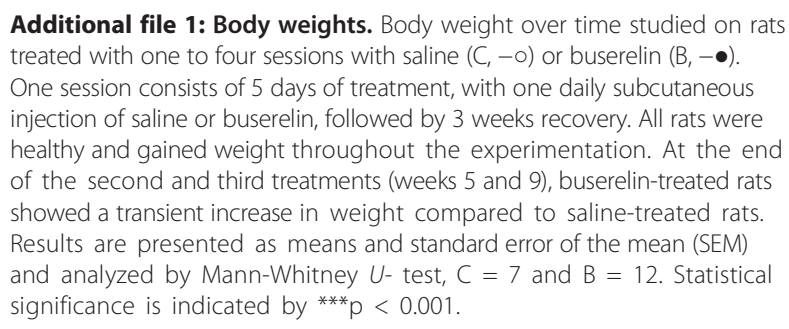

Additional file 2: Plasma estradiol levels. Estradiol (E2) plasma levels in rats, day 0 and 5 , of the fourth treatment session with saline (C) or buserelin (B). The rats receiving buserelin had already high levels of estradiol, at start of the last treatment session (session 4) compared to saline-treated rats $(p<0.05)$. Estradiol levels were still high day 5 in buserelin- compared to saline-treated rats $(p<0.05)$, indicating a sustained buserelin-induced high estrogen activity. Results are presented as medians and analyzed by Mann-Whitney $U$-test, $C=6$ and $B=12$. Statistical significance is indicated by ${ }^{*} p<0.05$.

Additional file 3: Vaginal smear characterization. Effects of buserelin or saline in individual rats on their estrus cycle. Vaginal smears were collected day 0 and 5 during session 1 and 4 . The classification of the different phases in estrus cycle were performed according to established criteria (Freeman 2006, Maldonao-Devinci 2010): - Proestrus (Pro) is characterized by the predominance of nucleated epithelial cells. - Estrus (E) is characterized by the predominance of anucleated cornified cells. Metestrus (M) is characterized by an equal portion of nucleated and anucleated epithelial cells and leukocytes. - Diestrus (D) is characterized by the predominance of leukocytes.

Additional file 4: Thickness of uterine muscle layers. Thicknesses of uterine muscle layer in rats treated with four sessions of saline (C) or buserelin (B). Buserelin-treated rats had hypertrophic uterine muscle layers compared to saline-treated rats. Results are presented as medians and analyzed by Mann-Whitney $U$ - test, $C=5$ and $B=12$. Statistical significance is indicated by $p<0.05$, which was considered statistically significant.

Additional file 5: Raw data. The number of enteric neruons in submucous ganglia (SG) and myenteric ganglia (MG) of fundus, ileum, and colon. The values of feces weight (g) and fat content (\% of dried feces) are given. The number of immunoreactive neurons in submucous ganglia (SG) in colon for somatostatin (som), expressed as \% of human neuronal protein HuC/D-immunoreactive neurons, from rats treated with four sessions of saline (controls) or buserelin. Link to the journal guidelines: http://www.biomedcentral.com.

\section{Abbreviations}

CGRP: Calcitonin gene-related peptide; CART: Cocaine- and amphetamine-related transcript (CART); ED: Enteric dysmotility; ENS: Enteric nervous system; E2: $17 \beta$ estradiol; FSH: Follicle-stimulating hormone; Gal: Galanin; GRP: Gastrin-releasing peptide; GnRH: Gonadotropin-releasing hormone; HuC/D: Human neuronal protein HuC/D; IBS: Irritable bowel syndrome; LH: Luteinizing hormone; MG: Myenteric ganglia; NOS: Nitric oxide synthases; NPY: Neuropeptide Y; Som: Somatostatin; SG: Submucous ganglia; SP: Substance P; VIP: Vasoactive intestinal peptide; VAchT: Vesicular acetylcholine transporter; 5-HT: Serotonin.

\section{Competing interests}

The authors declare that they have no competing interests.

\section{Authors contributions}

All authors made substantial contributions to the conception and design of the study, participated in the interpretation of the statistical analysis, and were involved in revising the manuscript critically for important intellectual content. ES performed the animal trials, performed some laboratory experiments, and made the statistical calculations. BR performed several laboratory analyses. PB performed some laboratory analyses. BO, ES, and EE wrote the manuscript and financed the study. All authors have read and approved the final manuscript.

\section{Acknowledgement}

The study was sponsored by the King Gustaf $V$ and Queen Victoria Free Mason s Foundation, Development of Region Skne, the Bengt Ihre Foundation, The Royal Physiographic Society in Lund, Ruth and Richard Julin s foundation, and Dir. Albert Phlsson s foundation. The skillful technical assistance provided by Anna Themner Persson is gratefully acknowledged. Peter Hglund is greatly acknowledged for statistical help and advices.

\section{Author details}

'Department of Clinical Sciences, Division of Internal Medicine Skne University Hospital, Lund University, Inga Marie Nilssons street 32, S-205 02 Malm, Sweden. ${ }^{2}$ Department of Experimental Medical Science, 
Neurogastroenterology Unit, BMC B11, Lund University, 22184 Lund, Sweden. ${ }^{3}$ Department of Biology, Functional Biology, Lund University, 22100 Lund, Sweden. ${ }^{4}$ Department of Medicinal Chemistry, CVMD, AstraZeneca, Mlndal, Sweden.

Received: 10 September 2014 Accepted: 28 November 2014 Published online: 11 December 2014

\section{References}

1. Ohlsson B, Verss B, Janciauskiene S, Montgomery A, Haglund M, Wallmark A: Chronic intestinal pseudo-obstruction due to buserelin-induced formation of anti-GnRH antibodies. Gastroenterology 2007, 132:45 51.

2. Hammar $\mathrm{O}^{*}$, Ohlsson B*, Veress B, Nordin Fredrikson G, Alm R, Montgomery A: Depletion of enteric gonadotropin-releasing hormone is found in a few patients suffering from severe gastrointestinal dysmotility. Scand J Gastroenterol 2012, 47:1165 1173. * $=$ Both are first authors.

3. Hammar O, Roth B, Bengtsson M, Mandl T, Ohlsson B: Autoantibodies and gastrointestinal symptoms in infertile women in relation to in vitro fertilization. BMC Pregnancy Childbirth 2013, 13:201.

4. Sand E, Voss U, Hammar O, Nordin Fredrikson G, Alm R, Ohlsson B, Ekblad E: Gonadotropin-releasing hormone analog buserelin causes neuronal loss in rat gastrointestinal tract. Cell Tissue Res 2013, 351:521 534

5. Ohlsson B, Sand E, Veress B: Ganglioneuritis is common in rats with enteric neuropathy due to buserelin treatment. Regul Pept 2014, 190 191:43 45.

6. Furness JB: The Enteric Nervous System. Oxford: Blackwell Publish Ltd; 2006.

7. Ekblad $E$, Mulder $H$, Sundler F: Vasoactive intestinal peptide expression in enteric neurons is upregulated by both colchicine and axotomy. Regul Pept 1996, 63:113 121.

8. Ekblad E, Sjuve R, Arner A, Sundler F: Enteric neuronal plasticity and a reduced number of interstitial cells of Cajal in hypertrophic rat ileum. Gut 1998, 42:836 844

9. Lindestrm LM, Ekblad E: Structural and neuronal changes in rat ileum after ischemia with reperfusion. Dig Dis Sci 2004, 49:1212 1222.

10. Arciszewski MB, Barabasz S, Całka J: Immunohistochemical localization of galanin receptors (GAL-R1, GAL-R2, and GAL-R3) on myenteric neurons from the sheep and dog stomach. Ann Anat 2008, 190:360 367.

11. Sand E, Themner-Persson A, Ekblad E: Infiltration of mast cells in rat colon is a consequences of ischemia/reperfusion. Dig Dis Sci 2008, 53:3158 3169.

12. Belai A, Boulos PB, Robson T, Burnstock G: Neurochemical coding in the small intestine of patients with Crohns disease. Gut 1997, 40:767 774

13. Schneider J, Jehle EC, Starlinger MJ, Neunlist M, Michel K, Hoppe S, Schemann M: Neurotransmitter coding of enteric neurons in the submucous plexus is changed in non-inflamed rectum of patients with Crohn s disease. Neurogastroenterol Motil 2001, 13:255 264.

14. Vera G, Castillo M, Cabezos PA, Chiarlone A, Martn MI, Gori A, Pasquinelli G, Barbara G, Stanghellini V, Corinaldesi R, De Giorgio R, Abalo R: Enteric neuropathy evoked by repeated cisplatin in the rat. Neurogastroenterol Motil 2011, 23:370 378

15. Voss U, Sand E, Olde B, Ekblad E: Enteric neuropathy can be induced by high fat diet in vivo and palmitic acid exposure in vitro. PLoS One 2013, 8:e81413.

16. Demedts I, Masaoka T, Kindt S, De Hertogh G, Geboes K, Farr R, Vanden Berghe P, Tack J: Gastrointestinal motility changes and myenteric plexus alterations in spontaneously diabetic biobreeding rats. J Neurogastroenterol Motil 2013, 19:161 170.

17. Trindade CR, Camargos AF, Pereira FEL: The effect of buserelin acetate on the uterus of adult rats: morphological aspects. Clin Exp Obstet Gynecol 2008, 3:198 201

18. Freeman ME: Neuroendocrine Control of the Ovarian Cycle of rat. In Knobil and Neills Physiology of Reproduction. 3rd edition. Edited by Neill JD, Plant TM, Pfaff DW, Challis JRG, de Kretser DM, Richards JS, Wassarman PM. Amsterdam: Elsevier; 2006:2328 2329.

19. Maldonado-Devinccci AM, Alipour KK, Michael LA, Kirstein CL: Repeated binge ethanol administration during adolescence enhances voluntary sweetened ethanol intake in young adulthood in male and female rats. Pharmacol Biochem Behav 2010, 96:476 487

20. Ekblad E, Kuhar M, Wierup N, Sundler F: Cocaine- and amphetamine-regulated transcript: distribution and function in rat gastrointestinal tract. Neurogastroenterol Motil 2003, 15:545 557
21. Zacharko-Siembida A, Kulik P, Szalak R, Lalak R, Arciszewski MB: Co-expression patterns of cocaine- and amphetamine-regulated transcript (CART) with neuropeptides in dorsal root ganglia of the pig. Acta Histochem 2014, 116:390 398

22. Ekblad E, Ekman R, Hkanson R, Sundler F: Projections of peptide-containing neurons in rat colon. Neurosci 1988, 27:655 674

23. Lin Z, Sandgren K, Ekblad E: Increased expression of vasoactive intestinal peptide in cultured myenteric neurons from rat small intestine. Auton Neurosci 2003, 107:9 19.

24. Ekblad E, Alm P, Sundler F: Distribution, origin and projections of nitric oxide synthase-containing neurons in gut and pancreas. Neuroscience 1994, 63:233 248 .

25. Kristensson E, Themner-Persson A, Ekblad E: Distribution, origin and projections of nitric oxide synthase-containing neurons in gut and pancreas. Regul Pept 2007, 140:109 116.

26. Mulder H, Ekelund M, Ekblad E, Sundler F: Islet amyloid polypeptide in the gut and pancreas: localization, ontogeny and gut motility effects. Peptides 1997, 18:771 783.

27. Lindestrm LM, Ekblad E: Origins and projections of nerve fibers in rat pyloric sphincter. Auto Neurosci 2002, 97:73 82.

28. Qian BF, Hammarstrm ML, Danielsson A: Differential expression of vasoactive intestinal polypeptide receptor 1 and 2 mRNA in murine intestinal T lymphocyte subtypes. J Neuroendocrinol 2001, 13:818 825.

29. Arvidsson U, Riedl M, Elde R, Meister B: Vesicular acetylcholine transporter (VAChT) protein: a novel and unique marker for cholinergic neurons in the central and peripheral nervous systems. J Comp Neurol 1997, 378:454 467.

30. Montelius C, Gustafsson K, Westrm B, Albertsson P, Emek SC, Rayner M, Erlansson-Albertsson: Chloroplast thylakoids reduce glucose uptake and decrease intestinal macromolecular permeability. Br J Nutr 2011, 106:836 844 .

31. Thymann T, Burrin DG, Tappenden KA, Bjornvad CR, Jensen SK, Sangild PT: Formula-feeding reduces lactose digestive capacity in neonatal pigs. Brit J Nutr 2006, 95:1075 1081.

32. Vanner S, Macnaughton WK: Submucosal secretomotor and vasodilator reflexes. Neurogastroenterol Motil 2004, 16(Suppl 1):39 43

33. Ekblad E, Winther C, Ekman R, Hkanson R, Sundler F: Projections of peptide-containing neurons in rat small intestine. Neuroscience 1987, 20:169 188 .

34. Ratnayake WM, Galli C: Fat and fatty acid terminology, methods of analysis and fat digestion and metabolism: a background review paper. Ann Nutr Metab 2009, 55:8 43.

35. Mourad FH, Saad NE: Neural regulation of intestinal nutrient absorption. Prog Neurobiol 2011, 95:149 162.

36. Hammar O, Veress B, Montgomery A, Ohlsson B: Expression of luteinizing hormone receptor in the gastrointestinal tract in patients with and without dysmotility. DTI 2012, 6:13 18.

37. Wright EM, Loo DD, Hirayama BA: Biology of human sodium glucose transporters. Physiol Rev 2011, 91:733 794

38. Cura AJ, Carruthers A: Role of monosaccharide transport proteins in carbohydrate assimilation, distribution, metabolism, and homeostasis. Compr Physiol 2012, 2:863 914.

39. Belchetz PE, PInt TM, Nakai Y, Keogh EJ, Knobil E: Hypophysial responses to continuous and intermittent delivery of hypothalamic gonadotropin-releasing hormone. Science 1978, 202:631 633.

40. Roa J, Vigo E, Castellano JM, Navarro VM, Fernndez-Fernndez R, Casanueva FF, Dieguez C, Aguilar E, Pinilla L, Tena-Sempere M: Hypothalamic expression of KiSS-1 system and gonadotropin-releasing effects of kisspeptin in different reproductive states of the female rat. Endocrinology 2006, 147:2864 2878

41. Salehi MS, Jafarzadeh Shirazi MR, Zamiri MJ, Pazhoohi F, Namavar MR, Niazi A Ramezani A, Tanideh N, Tamadon A, Zarei A: Hypothalamic expression of KiSS1 and RFamide-related Peptide-3 mRNAs during the estrous cycle of rats. Int J Fertil Steril 2013, 6:304 309.

42. Naor Z: Signalling by G-protein-coupled receptor (GPCR): studies on the GnRH receptor. Front Neuroendocrinol 2009, 30:10 29.

43. Campbell-Thompson M, Reyher KK, Wilkinson LB: Immunolocalization of estrogen receptor alpha and beta in gastric epithelium and enteric neurons. J Endocrinol 2001, 171:65 73

44. Fasano A: Zonulin, regulation of tight junctions, and autoimmune diseases. Ann N Y Acad Sci 2012, 1258:25 33. 
45. Canavan C, West J, Card T: The epidemiology of irritable bowel syndrome. Clin Epidemiol 2014, 6:71 80.

46. Hughes PA, Zola H, Penttila IA, Blackshaw LA, Andrews JM, Krumbiegel D: Immune activation in irritable bowel syndrome: can neuroimmune interactions explain symptoms? Am J Gastroenterol 2013, 108:1066 1074.

47. Crane C, Martin M: Perceived vulnerability to illness in individuals with irritable bowel syndrome. J Psychosom Res 2002, 53:1115 1122.

48. Drossman DA, McKee DC, Sandler RS, Mitchell CM, Cramer EM, Lowman BC, Burger AL: Psychological factors in the irritable bowel syndrome. A multivariate study of patients and nonpatients with irritable bowel syndrome. Gastroenterology 1988, 95:701 708

49. Dorn SD, Palsson OS, Thiwan SI, Kanazawa M, Clark WC, van Tilburg MA, Drossman DA, Scarlett Y, Levy RL, Ringel Y, Crowell MD, Olden KW, Whitehead WE: Increased colonic pain sensitivity in irritable bowel syndrome is the result of an increased tendency to report pain rather than increased neurosensory sensitivity. Gut 2007, 56:1202 1209.

50. Elsenbruch S, Rosenberger C, Enck P, Forsting M, Schedlowski M, Gizewski ER: Affective disturbances modulate the neural processing of visceral pain stimuli in irritable bowel syndrome: an fMRI study. Gut 2010, 59:489 495 .

51. Larsson MB, Tillisch K, Craig AD, Engstrm M, Labus J, Naliboff B, Lundberg P, Strm M, Mayer EA, Walter SA: Brain responses to visceral stimuli reflect visceral sensitivity thresholds in patients with irritable bowel syndrome. Gastroenterology 2012, 142:463 472. e3.

52. Keszthelyi D, Troost FJ, Jonkers DM, Helyes Z, Hamer HM, Ludidi S, Vanhoutvin S, Venema K, Dekker J, Szolcsnyi J, Masclee AA: Alterations in mucosal neuropeptides in patients with irritable bowel syndrome and ulcerative colitis in remission: a role in pain symptom generation? Eur J Pain 2013, 9:1299 1306

doi:10.1186/s12876-014-0209-7

Cite this article as: Sand et al: Structural and functional consequences of buserelin-induced enteric neuropathy in rat. BMC Gastroenterology 2014 14:209.

\section{Submit your next manuscript to BioMed Central and take full advantage of:}

$凶$ Convenient online submission

$\otimes$ Thorough peer review

$\otimes$ No space constraints or color $\bowtie$ gure charges

$\bigotimes$ Immediate publication on acceptance

Q Inclusion in PubMed, CAS, Scopus and Google Scholar

$\otimes$ Research which is freely available for redistribution 